\title{
Influence of transport and ocean ice extent on biogenic aerosol sulfur in the Arctic atmosphere
}

\author{
S. Sharma, ${ }^{1}$ E. Chan, ${ }^{1}$ M. Ishizawa, ${ }^{1}$ D. Toom-Sauntry, ${ }^{1}$ S. L. Gong, ${ }^{1}$ S. M. Li, ${ }^{1}$ \\ D. W. Tarasick, ${ }^{1}$ W. R. Leaitch, ${ }^{1}$ A. Norman, ${ }^{2}$ P. K. Quinn, ${ }^{3}$ T. S. Bates, ${ }^{3}$ M. Levasseur, ${ }^{4}$ \\ L. A. Barrie, ${ }^{5}$ and W. Maenhaut ${ }^{6}$
}

Received 27 October 2011; revised 8 May 2012; accepted 15 May 2012; published 30 June 2012.

[1] The recent decline in sea ice cover in the Arctic Ocean could affect the regional radiative forcing via changes in sea ice-atmosphere exchange of dimethyl sulfide (DMS) and biogenic aerosols formed from its atmospheric oxidation, such as methanesulfonic acid (MSA). This study examines relationships between changes in total sea ice extent north of $70^{\circ} \mathrm{N}$ and atmospheric MSA measurement at Alert, Nunavut, during 1980-2009; at Barrow, Alaska, during 1997-2008; and at Ny-Ålesund, Svalbard, for 1991-2004. During the 1980-1989 and 1990-1997 periods, summer (July-August) and June MSA concentrations at Alert decreased. In general, MSA concentrations increased at all locations since 2000 with respect to 1990 values, specifically during June and summer at Alert and in summer at Barrow and Ny-Ålesund. Our results show variability in MSA at all sites is related to changes in the source strengths of DMS, possibly linked to changes in sea ice extent as well as to changes in atmospheric transport patterns. Since 2000, a late spring increase in atmospheric MSA at the three sites coincides with the northward migration of the marginal ice edge zone where high DMS emissions from ocean to atmosphere have previously been reported. Significant negative correlations are found between sea ice extent and MSA concentrations at the three sites during the spring and June. These results suggest that a decrease in seasonal ice cover influencing other mechanisms of DMS production could lead to higher atmospheric MSA concentrations.

Citation: Sharma, S., et al. (2012), Influence of transport and ocean ice extent on biogenic aerosol sulfur in the Arctic atmosphere, J. Geophys. Res., 117, D12209, doi:10.1029/2011JD017074.

\section{Introduction}

[2] The oceanic production of dimethyl sulfide (DMS) results from a suite of abiotic and biotic processes involving most components of the food web [Simó, 2001]. In the Arctic, phytoplankton and ice algae contribute to the production of dimethylsulfoniopropionate (DMSP), the precursor of DMS [Levasseur et al., 1994; Leck and Persson,

\footnotetext{
${ }^{1}$ Science and Technology Branch, Environment Canada, Toronto, Ontario, Canada.

${ }^{2}$ Department of Physics and Astronomy, University of Calgary, Calgary, Alberta, Canada. USA.

${ }^{3}$ Pacific Marine Environmental Laboratory, NOAA, Seattle, Washington,

${ }^{4}$ Département de Biologie, Université Laval, Quebec, Quebec, Canada.

${ }^{5}$ Cyprus Institute, Nicosia, Cyprus.

${ }^{6}$ Department of Analytical Chemistry, Ghent University, Gent, Belgium.

Corresponding author: S. Sharma, Science and Technology Branch, Environment Canada, Toronto, ON M3H 5T4, Canada.

(sangeeta.sharma@ec.gc.ca)

Published in 2012 by the American Geophysical Union.
}

1996; Gosselin et al., 1997]. Some DMS near the ocean surface diffuses into the atmosphere or is ventilated by wave action. Once in the atmosphere, DMS is oxidized to produce sulfate and methanesulfonate (MSA) via $\mathrm{SO}_{2}$ oxidation pathway. MSA may condense onto atmospheric aerosol particles. $\mathrm{SO}_{2}$ may react with existing particles or it can be further oxidized to $\mathrm{H}_{2} \mathrm{SO}_{4}$, which either condenses on existing particles or nucleates new particles [Kulmala et al., 2007]. These sulfur components increase the size of particles on which they condense and generally increase the particle's hygroscopicity, which enhances its CCN activity [Petters and Kreidenweis, 2007]. Moreover, DMS oxidation products formed further over the ice pack condense on the locally produced soluble [Hawkins and Russell, 2010; Russell et al., 2010] and insoluble [Bigg and Leck, 2008; Ceburnis et al., 2008; Facchini et al., 2008; Hawkins and Russell, 2010; O'Dowd et al., 2004] organic particles formed from bubble bursting [Leck et al., 2002; Leck and Bigg, 2005b] and from other oceans [Hawkins and Russell, 2010; Ceburnis et al., 2008; Facchini et al., 2008; O'Dowd et al., 2004; Bigg and Leck, 2008]. These organics that contribute to the $\mathrm{CCN}$ activity are suggested to be exopolymer secretions which are microcolloids and their gels [Leck and 


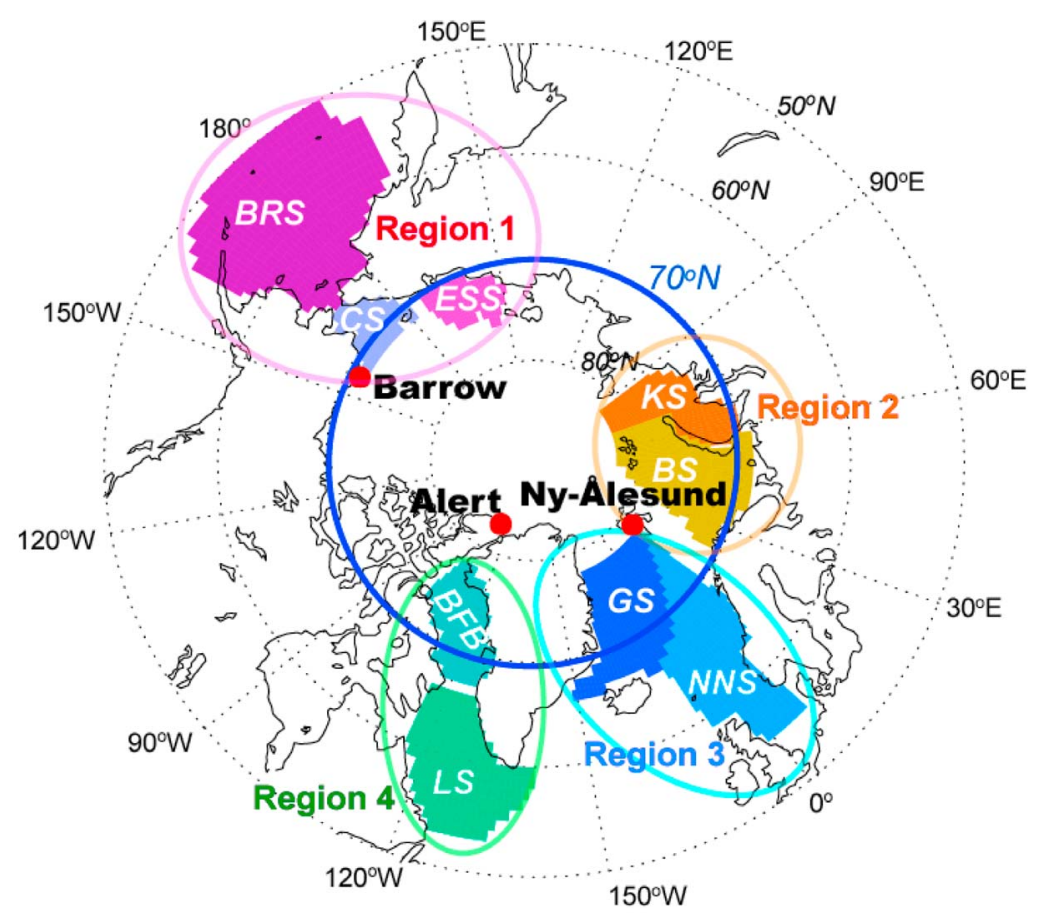

Figure 1. Polar stereographic projection of the Arctic region that exhibits different potential MSA source regions and the relative locations of the three measurement sites: Alert in Ellesmere Island, Barrow in Alaska, and $\mathrm{Ny}-\AA ̊$ Allesund in Svalbard. Various colors represent approximate regions included to determine sea ice extent.

Bigg, 2005a], lipopolysaccharides [Facchini et al., 2008] and biological sugars [Russell et al., 2010]. Charlson et al. [1987] hypothesized that new particles formed from DMS oxidation can impact climate by enhancing cloud reflectance (CLAW), but there has been little evidence to support local feedbacks as suggested by this hypothesis [Quinn and Bates, 2011]. Besides enhancing climate-related aspects of the aerosol, MSA also serves as a tracer for oceanic sources of particles and changes in MSA may reflect changes in the availability of such sources.

[3] Since the decline in sea ice coverage in the Arctic over the past decade [Serreze et al., 2007; http://nsidc.org/ arcticseaicenews], there has been a $22 \%$ increase in annual primary productivity that has been attributed to a longer phytoplankton growing season [Arrigo et al., 2008]. Modeling results in Gabric et al. [2005] suggest that an increase in DMS production would result from the retreat of the ice cover and its accompanied increase in primary production. Furthermore, analysis of stable sulfur isotopes in the aerosol particles at Alert [Norman et al., 2005] suggests that the biogenic component of sulfur in those particles increased by $14 \%$, relative to the anthropogenic contribution, between 1993 and 2003.

[4] In the present study, we use 29 years of atmospheric MSA measurements at Alert, 11 years at Barrow (Alaska, USA) and 14 years at Ny-Ålesund (Svalbard, Norway) to document the changes in MSA concentrations and look for evidence of trends related to variations in sea ice extent. The connections of MSA to sea ice extent, atmospheric transport patterns, and changes in source regions are explored for the spring and summer periods, when phytoplankton productivity in the source regions and MSA concentrations at the measurement sites are the highest.

\section{Method}

[5] Alert $\left(82^{\circ} \mathrm{N}, 62.3^{\circ} \mathrm{W}, 250 \mathrm{~m}\right.$ asl $)$ is located at the northern tip of Ellesmere Island in the Canadian high Arctic, Point Barrow $\left(71^{\circ} \mathrm{N}, 156.6^{\circ} \mathrm{W}\right.$, sea level) is on the northern coast of Alaska in the northwestern Arctic, and $\mathrm{Ny}-\mathrm{A} l$ lesund $\left(79^{\circ} \mathrm{N}, 12^{\circ} \mathrm{E}, 474 \mathrm{~m}\right.$ asl $)$ is in the northeastern Arctic in Svalbard, Norway (Figure 1). Weekly integrated samples of aerosol particles were collected on $20 \times 25 \mathrm{~cm}^{2}$ Whatman 41D filters with no size cut at Alert; integrated air volumes were approximately $16,000 \mathrm{~m}^{3}$. At Barrow, samples were collected with a Berner-type multijet cascade impactor with aerodynamic $\mathrm{D}_{50}$ cutoff diameters of 1 and $10 \mu \mathrm{m}$. Sample volumes of $43 \mathrm{~m}^{3}$ to $172 \mathrm{~m}^{3}$ were collected depending on time of year. Samples at Ny-Ålesund were collected at a flow rate of $1.3 \mathrm{~m}^{3} \mathrm{~min}^{-1}$ by a modified Sierra-Andersen Hi-Vol cascade impactor in fine and coarse fractions defined by $<2.5 \mu \mathrm{m}$ and $>2.5 \mu \mathrm{m}$ aerodynamic $\mathrm{D}_{50}$ cutoff diameter. Analyses of several coarse size fraction samples indicated that $90 \%$ or more of all MSA was in the fine size fraction [Maenhaut et al., 1997]. Three samples were collected per week for 2-2-3 day schedule giving total volume between 3774 and $5616 \mathrm{~m}^{3}$. Some differences in the MSA concentrations measured at the three sites may be due to differences in the aerosol collection techniques and size cuts.

[6] Samples from the three sites were analyzed for MSA by ion chromatography. Details of the sampling inlet, handling 


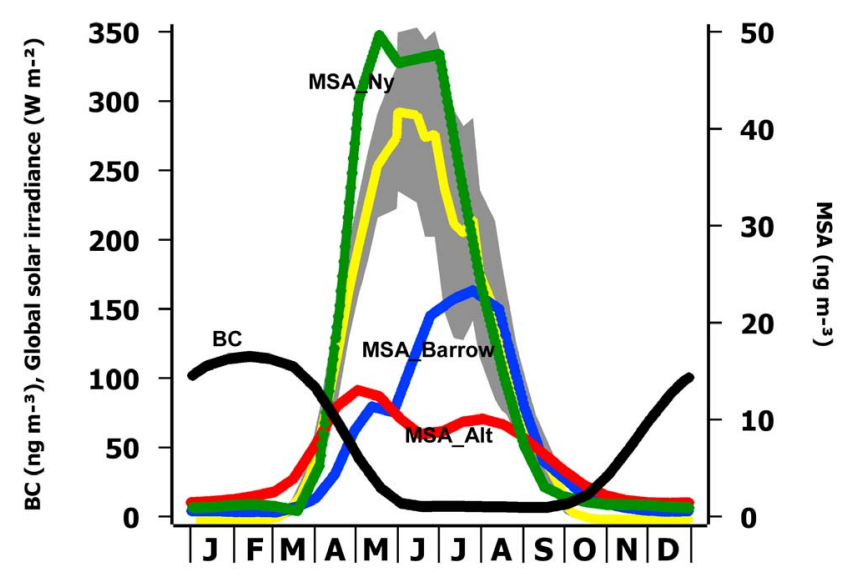

Figure 2. Seasonal variation in MSA at Alert in $\mathrm{ng} \mathrm{m} \mathrm{m}^{-3}$ (red line), Barrow (blue line), Ny-Ålesund (green line), black carbon in $\mathrm{ng} \mathrm{m}^{-3}$ (black line), and global solar irradiation in $\mathrm{W} \mathrm{m}{ }^{-2}$ (yellow line) from 1980 to 2003 measured at Alert, Nunavut. The standard deviation in the solar irradiance is given by the shaded gray regions above and below the mean curve indicative of the abundance of cloud cover during the summer when MSA is higher.

procedures and chemical analyses can be found in $L i$ and Barrie [1993] for Alert, Quinn et al. [2002] for Barrow, and Maenhaut et al. [1994, 2002] and Maenhaut [1997] for Ny-Ålesund. The variance in the data and the trends due to methodology is minimal as similar stringent procedures have been applied at all sites over the time periods used in this paper. The detection limits for MSA concentrations are $0.15,0.4$ and $0.05 \mathrm{ng} \mathrm{m}^{-3}$ for Alert, Barrow and $\mathrm{Ny}$-Ålesund samples, respectively.

[7] Transport was assessed by using 7 day back trajectories, calculated with the National Oceanic Atmospheric Administration (NOAA) HYSPLIT model (available at http:// ready.arl.noaa.gov/HYSPLIT.php) at $925 \mathrm{hPa}$. A k means clustering technique [Dorling et al., 1992], based on Euclidean distance, was used to sort the 7 day air parcel backward trajectories from 1980 through 2009 into four trajectory clusters for each of the three sites linking back to the source regions as shown in different colors in Figure 1. The source regions are as follows: region 1, Bering (BRS)/Chukchi Seas (CS)/East Siberian Sea (ESS); region 2, Kara (KS)/Barents Seas (BS); region 3, Norwegian/North Seas (NNS)/Greenland Sea (GS); and region 4, Baffin Bay (BFB)/Labrador Sea (LS). Plots of Potential Source Contribution Function (PSCF) were generated using the method of Seibert et al. [1994]. This technique associates 7 day back trajectories with MSA concentrations based on the frequency of trajectories through each grid cell. The value in each grid cell then represents the trajectory weighted mean MSA concentrations. The association of the higher MSA concentrations at any site with the nearest open water region was assumed to identify source regions with greater potential for DMS production. Sea ice concentrations data sets were obtained from the NOAA data center (http:// www.cdc.noaa.gov/data/gridded/data.noaa.oisst.v2.html). Decadal variations in MSA and the parameters that influence MSA concentrations were assessed. These reporting periods were determined from the seasonal cycle in MSA observations and the decades were determined by the changes in trends in the MSA concentrations at Alert.

[8] Sea ice extent was estimated by combining grid cells with sea ice greater than $15 \%$ over different areas (north of $70^{\circ} \mathrm{N}, \mathrm{BFB}, \mathrm{NNS}, \mathrm{BRS} / \mathrm{CS}$, and $\mathrm{KS} / \mathrm{BS}$ regions highlighted in Figure 1); values less than $15 \%$ are assumed to be open ocean (http://nsidc.org/seaice/data/terminology.html). The uncertainty in the extraction of sea ice data is $\pm 15-20 \%$ during the summer and $\pm 10 \%$ during the spring and fall (T. Agnew, personal communication, 2010). The marginal ice zone (MIZ) doesn't have a clear definition as this is a boundary between the open ocean and totally ice-covered ocean. In previous studies, it has been considered as a region with less than 40\% ice cover [Matrai and Vernet, 1997]. A more detailed breakdown also has been used as in Leck and Persson [1996] where the Inner Ice Edge Zone (IIEZ) was defined by less than 40 to $80 \%$ ice cover. In this study, any region with sea ice extent of less than $60 \%$ is defined as the Marginal sea ice Zone (MIZ), an area known for its recurring algal blooms [Perrette et al., 2011] and high water DMS concentrations [Leck and Persson, 1996]. These blooms extend several hundred kilometers toward the open water from the ice edge [Leck and Persson, 1996; Perrette et al., 2011]. At higher latitudes, close to the permanent sea ice, the MIZ is found to be up to 1.5-2 times more productive than open water [Perrette et al., 2011]. Our Seibert analysis was adjusted by applying a DMS concentration weighted function along the trajectory pathways as follows: (1) a DMS source function of zero was applied over the frozen surfaces for sea ice extent greater than $60 \%$ and (2) a factor of 1 was applied to the Seibert output for sea ice extent less than and equal to $60 \%$.

\section{Results}

\subsection{Seasonal Variation in MSA}

[9] The results in this section are grouped into three time periods based on the seasonal cycle in MSA for the following periods: April-May (generally corresponding to the spring algal bloom at middle and high latitudes), June (transition period), and July-August (summer period).

[10] The seasonal cycles in MSA at the three sampling sites are presented in Figure 2. MSA concentrations peak on average at $10 \mathrm{ng} \mathrm{m}^{-3}$ in the spring (April-May) at Alert (red) and at $20 \mathrm{ng} \mathrm{m}^{-3}$ in the summer (July-August) at Barrow (blue) [see also Li and Barrie, 1993; Quinn et al., 2007]. At $\mathrm{Ny}$-Ålesund, the increase in MSA concentrations (green) occurred in late March, MSA remained elevated from beginning of May until mid-July; and declined faster than at the other two sites [Maenhaut et al., 1997]. On average, MSA levels were 2.5 and 5 times higher at $\mathrm{Ny}$-Ålesund than at Barrow and Alert. The increase in MSA in the spring and its decrease in the fall are coincident with the seasonal cycle of solar irradiance (indicated by yellow line in Figure 2) at the sites. MSA is produced through the photochemical oxidation of DMS during the spring and summer by $\mathrm{OH}$ as well as by halogens such as BrO radicals that are more abundant in the Arctic springtime [von Glasow and Crutzen, 2004]. MSA levels peak at all three sites during April-May when transport from midlatitudes is in decline; the decline in midlatitude transport is represented here by the measurements of black carbon (BC) (anthropogenic indicator) at Alert [Barrie, 1986; 
(a) Alert

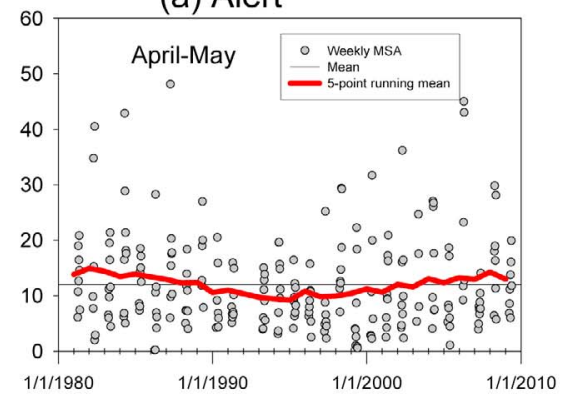

(b) Alert

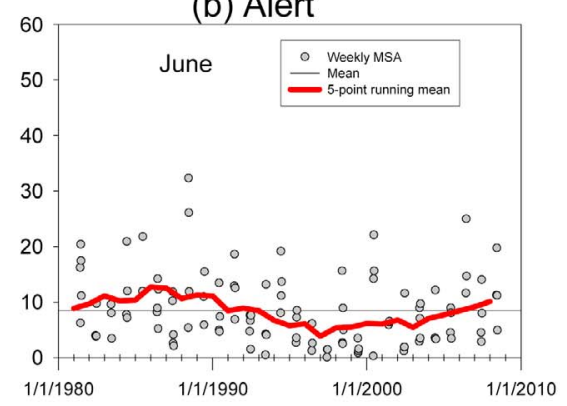

(c) Alert

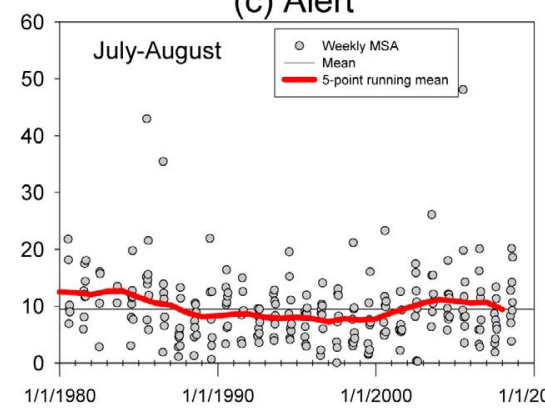

(d) Barrow

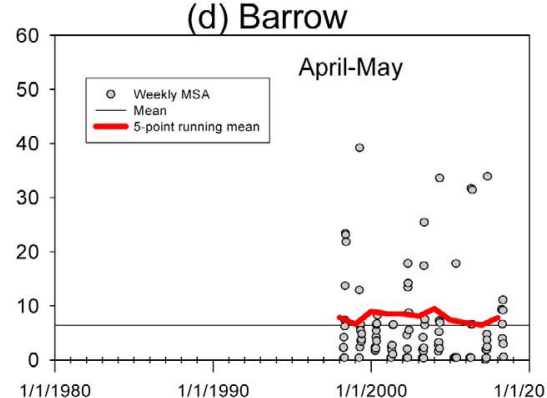

(e) Barrow

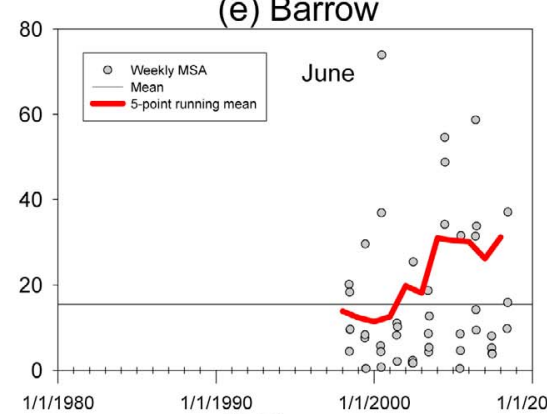

(f) Barrow

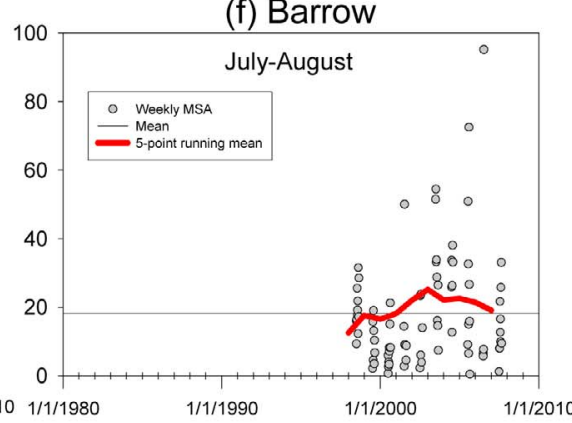

(g) Ny-Ålesund

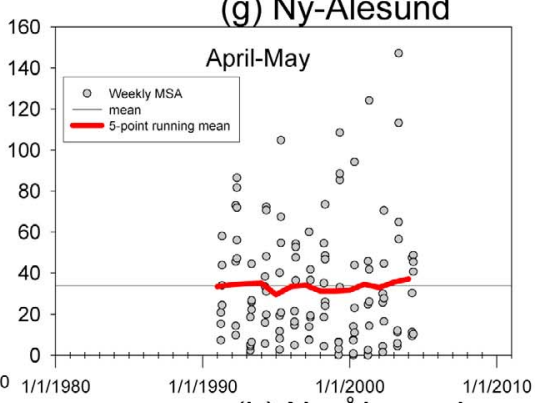

(h) Ny-Âlesund
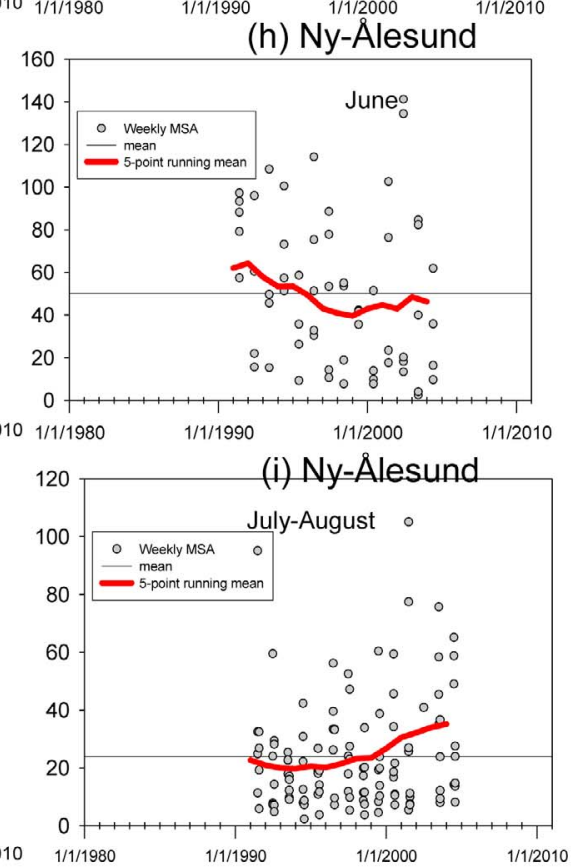

Figure 3. Weekly MSA at all locations (gray circles) and five-point running average (red line) of mean MSA concentrations for (a, d, g) April-May, (b, e, h) June, and (c, f, i) July-August at Alert from 1980 to 2009, Barrow from 1997 to 2008, and Ny-Ålesund from 1991 to 2004. Increasing MSA concentrations are evident at all sites since 1998 in July-August.

Sharma et al., 2004]. A second peak in MSA occurs at all sites, most notably Barrow and Alert, during the summer months (July and August). At Alert, the summer peak is representative of local MSA sources, while the spring peak is influenced by MSA from generally more distant sources [Li et al., 1993].

[11] Boundary layer height is potentially an important consideration when comparing atmospheric MSA concentrations between sites. Low-level inversions $(<200 \mathrm{~m})$ can form over Arctic ice and open water, which will affect the degree of coupling between surface DMS emissions and sampling sites at Ny-Ålesund and Alert which are both a few hundred meters above sea level. Boundary layer estimation in the Arctic is an active area of research and is beyond the scope of this paper. However, an examination of ozonesonde data from the World Ozone and UV Data Centre (WOUDC) (available at http://www.woudc.org/) and radiosonde data from the Integrated Global Radiosonde Archive (IGRA) (available at http://www1.ncdc.noaa.gov/pub/data/igra/), using several methods of estimating boundary layer height [Seibert et al., 2000; Seidel et al., 2010] shows no significant trends after 2000 at any of the three sites, nor do the interannual variations appear to correlate in any way with the variations in MSA observed (results not shown here).

\subsection{MSA Time Series}

[12] MSA concentrations displaying five-point running mean at Alert, Barrow, and $\mathrm{Ny}$-Ålesund for the months of April-May, June, and July-August are shown in Figure 3. Although the time period is short with 29 years of MSA data only at Alert, there are significant changes in observed MSA as determined by this analysis. MSA concentrations at Alert appear to have decreased from 1980 to 1989 and subsequently increased again after 2000. However, the changes in MSA during 1980-1989 were only significant for the July-August time period with decreasing trends of $4 \%$ $\mathrm{yr}^{-1}(\mathrm{p}=0.025)$, consistent with Li et al. [1993]. Over the period 1991-1997, MSA concentrations showed little change during April-May but decreased in June by $9 \% \mathrm{yr}^{-1}(\mathrm{p}=$ 0.025). From 1998 to 2009, MSA concentrations increased at 
Table 1. Averaged ( \pm 1 SD) and Median MSA Concentrations for April-May, June, and July-August Periods at Alert, Barrow, and Ny-Ålesund Separated by 1980-1989, 1990-1999, and 2000-2009

\begin{tabular}{|c|c|c|c|c|c|c|c|c|c|}
\hline & \multicolumn{9}{|c|}{$\operatorname{MSA}\left(\mathrm{ngm}^{-3}\right) \pm \mathrm{SD}$} \\
\hline & \multicolumn{3}{|c|}{ April-May } & \multicolumn{3}{|c|}{ June } & \multicolumn{3}{|c|}{ July-August } \\
\hline & Mean & Median & $\Delta(\% / y r)$ & Mean & Median & $\Delta(\% / y r)$ & Mean & Median & $\Delta(\% / \mathrm{yr})$ \\
\hline \multicolumn{10}{|l|}{ Alert } \\
\hline 1980-1989 & $14 \pm 9$ & 12 & NS & $11 \pm 7$ & 11 & NS & $11 \pm 7$ & 11 & $-4.2^{\mathrm{b}}$ \\
\hline $1990-1997$ & $10 \pm 6$ & 8 & NS & $7 \pm 5$ & 5 & $-9^{\mathrm{b}}$ & $8 \pm 4$ & 8 & NS \\
\hline 1998-2009 & $12 \pm 10$ & 10 & NS & $8 \pm 6$ & 6 & $+7^{\mathrm{b}}$ & $10 \pm 7$ & 9 & $+4.5^{\mathrm{b}}$ \\
\hline \multicolumn{10}{|l|}{ Barrow } \\
\hline 1998-2009 & $6 \pm 8$ & 4 & NS & $19 \pm 8$ & 15 & NS & $20 \pm 20$ & 14 & $+8.3^{\mathrm{c}}$ \\
\hline \multicolumn{10}{|l|}{ Ny-Ålesund } \\
\hline 1991-1997 & $37 \pm 37$ & 25 & NS & $56 \pm 49$ & 48 & NS & $26 \pm 24$ & 19 & NS \\
\hline $1998-2004$ & $42 \pm 33$ & 38 & NS & $43 \pm 18$ & 18 & NS & $42 \pm 47$ & 27 & $+7.3^{\mathrm{b}}$ \\
\hline
\end{tabular}

${ }^{\text {a }}$ Significant changes in MSA since 1998 are also evident in July-August at all locations.

${ }^{\mathrm{b}}$ Significant to 0.025 level $(t$ test).

'Significant to 0.1 level $(t$ test $)$.

the rates $7 \% \mathrm{yr}^{-1}$ and $4.5 \% \mathrm{yr}^{-1}$ during June and July-August (both $\mathrm{p}=0.025$ ) at Alert, respectively.

[13] At Barrow, MSA concentrations exhibited no significant change during the April-May and June period. In July-August, there was an overall change of $8.3 \% \mathrm{yr}^{-1}$ at $90 \%$ significance level $(\mathrm{p}=0.1)$ from 1998 to 2008 . Quinn et al. [2009] showed an increase of $13 \% \mathrm{yr}^{-1}$ from 1998 to 2008 at Barrow for combined MSA data from July to September, which is consistent with the results presented here. However, we note that in the time series of MSA at Alert and Barrow there are no clear changes in MSA concentrations associated with the largest decline in the sea ice extent which occurred in September 2007. Usually MSA levels are low by September as the solar irradiance is close to its minimum (see Figure 2).

[14] At Ny-Ålesund, increases in mean MSA concentrations are evident since 1998 at this site, with a significant increase of $7.3 \% \mathrm{yr}^{-1}(\mathrm{p}=0.025)$ in July-August. All MSA data from the three sites are also presented in Table 1 showing averaged MSA concentrations with standard deviations and median values. Trends are shown only where they are statistically significant.

\subsection{Determination of Dominant Air Pathways From Trajectory Analysis}

[15] The dominant air pathways from the potential MSA source regions to the measurement sites are summarized in Table 2. Four clusters were generated from 7 day back trajectories for the three decades at Alert, for the 2000-2009 at Barrow and for the 1990-1999 at Ny-Ålesund. In all three decades, the dominant air pathways during spring and summer at Alert are from region 3 (NNS). In comparison to the 1980-1989 period, there is a $10 \%$ decrease in the frequency of trajectories at Alert from region 3 (NNS) corresponding to an increase from region 1 (BRS/CS/ESS) during the 19901999 period. During 2000-2009, Barrow is predominantly influenced by air pathways from the direction of regions 1 (BRS/CS/ESS) and 4 (BFB). At Ny-Ålesund, the highest frequency of trajectories for the 1990-1999 period is from region $2(\mathrm{BS} / \mathrm{KS})$ in the spring and region $3(\mathrm{NNS})$ in the

Table 2. Decadal Percent Frequencies of 7 Day Back Trajectories Arriving at Alert, Barrow, and Ny-Ålesund From Four Clusters That Include the MSA Source Regions in the Spring and Summer ${ }^{\mathrm{a}}$

\begin{tabular}{|c|c|c|c|c|c|c|c|c|c|}
\hline \multirow[b]{4}{*}{ Region } & \multirow[b]{4}{*}{ Location } & \multicolumn{8}{|c|}{7 Day Back Trajectory Cluster Analysis ${ }^{b}$} \\
\hline & & \multirow{3}{*}{$\begin{array}{c}\text { Primary } \\
\text { Production } \\
\left(\mathrm{g} \mathrm{C}^{2} \mathrm{~cm}^{2}\right)^{\mathrm{c}}\end{array}$} & \multirow[b]{3}{*}{ Site } & \multicolumn{6}{|c|}{ Percent Frequency From Cluster } \\
\hline & & & & \multicolumn{2}{|c|}{ 1980-1989 } & \multicolumn{2}{|c|}{ 1990-1999 } & \multicolumn{2}{|c|}{ 2000-2009 } \\
\hline & & & & Apr-May & Jul-Aug & Apr-May & Jul-Aug & Apr-May & Jul-Aug \\
\hline \multirow[t]{3}{*}{1} & Bering Sea (BRS) and Chukchi Sea (CS) & $>230$ & Alert & $14 \%$ & $20 \%$ & $25 \%$ & $35 \%$ & $20 \%$ & $24 \%$ \\
\hline & & & Barrow & & & & & $38 \%$ & $47 \%$ \\
\hline & East Siberian (ESS) & $20-40$ & Ny-Ålesund & & & $21 \%$ & $15 \%$ & & \\
\hline \multirow[t]{3}{*}{2} & Barents Sea $(\mathrm{BS}) /$ Kara Sea $(\mathrm{KS})$ & $20-200$ & Alert & $19 \%$ & $18 \%$ & $17 \%$ & $18 \%$ & $16 \%$ & $15 \%$ \\
\hline & & & Barrow & & & & & $28 \%$ & $29 \%$ \\
\hline & & & Ny-Ålesund & & & $42 \%$ & $25 \%$ & & \\
\hline 3 & Norwegian/North Sea (NNS) & $80-150$ & $\begin{array}{c}\text { Alert } \\
\text { Barrow }\end{array}$ & $49 \%$ & $35 \%$ & $38 \%$ & $23 \%$ & $45 \%$ & $36 \%$ \\
\hline \multirow{4}{*}{4} & & & Ny-Ålesund & & & $25 \%$ & $44 \%$ & & \\
\hline & Baffin Bay/Canadian Shield (BFB) & $60-120$ & Alert & $17 \%$ & $27 \%$ & $20 \%$ & $24 \%$ & $20 \%$ & $24 \%$ \\
\hline & & & Barrow & & & & & $34 \%$ & $24 \%$ \\
\hline & & & Ny-Ålesund & & & $12 \%$ & $16 \%$ & & \\
\hline
\end{tabular}

${ }^{a}$ Primary productivities in the source regions of MSA that are also high in water DMS [Lana et al., 2011] are also given.

${ }^{\mathrm{b}}$ Four clusters were generated from 7 day back trajectories by using the Dorling et al. [1992] technique.

${ }^{\mathrm{c}}$ Primary productivity in different source regions of MSA [Hunt et al., 2002; Loeng et al., 2005]. 


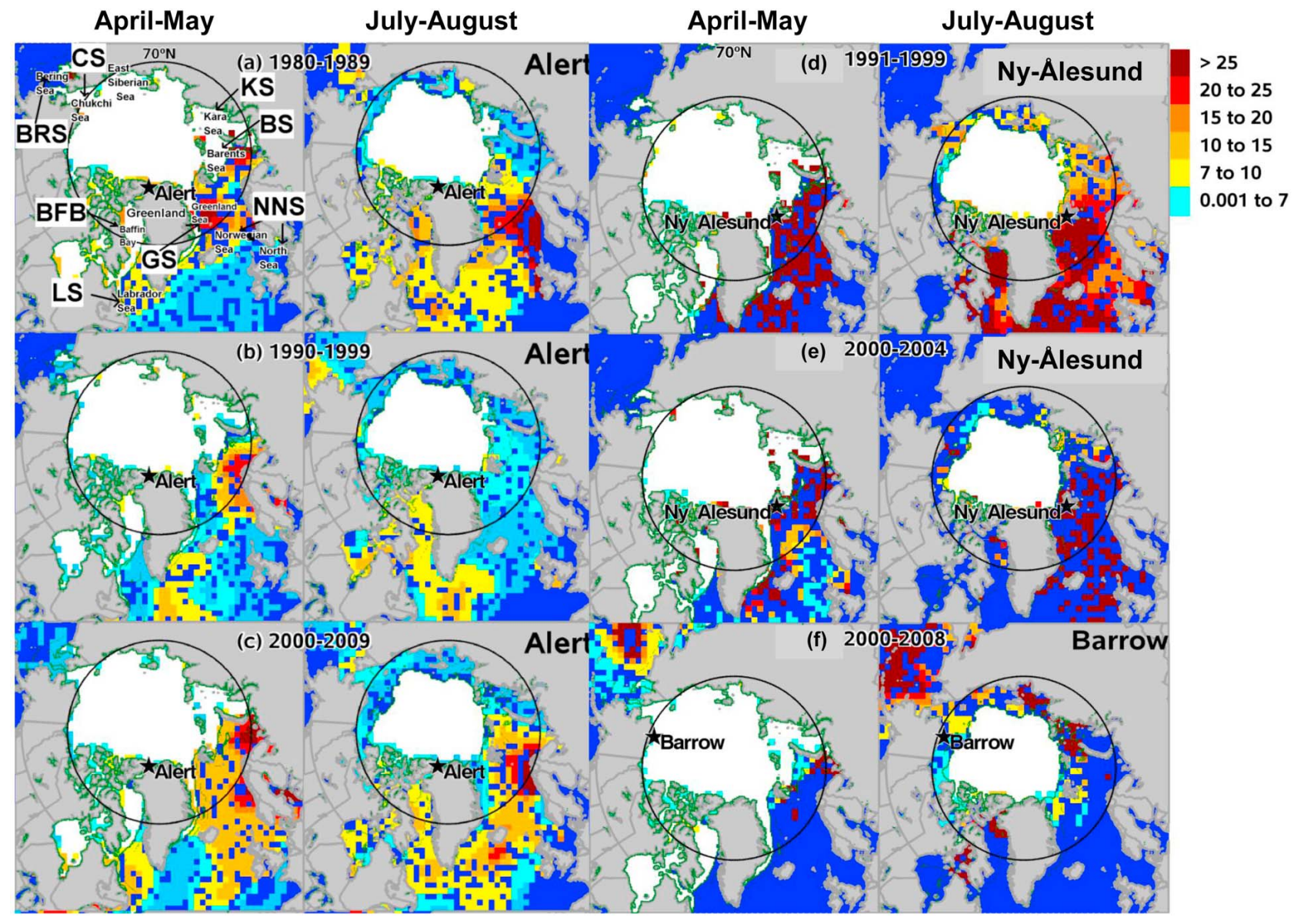

Figure 4. The 7 day back trajectory weighted MSA concentrations (weighted Seibert analysis plots) for April-May and July-August show changes in potential MSA source regions at Alert for (a) 1980-1989, (b) 1990-1999, and (c) 2000-2009; at Ny-Ålesund for (d) 1991-1999 and (e) 2000-2004; and at Barrow for (f) 2000-2008. A DMS source function of zero was applied when sea ice concentration was $>60 \%$, and one was applied for sea ice concentrations $<60 \%$. The movement of the ice edge $(50-60 \%$ sea ice extent, green edge) is apparent especially in the western part of the Arctic in Figure 4c. The unit for color coding is $\mathrm{ng} \mathrm{m}^{-3}$.

summer. Decadal comparison of the $\%$ frequencies in the 4 clusters is not possible for Barrow and Ny-Ålesund due to shorter time series of MSA data at these sites.

[16] Inventories of seawater DMS are limited in the Arctic region [Kettle et al., 1999; Leck and Persson, 1996]. Recent reconstitution of the Kettle et al. [1999] DMS inventory with inclusion of new DMS measurements generated an updated climatology of surface DMS concentrations [Lana et al., 2011]. The new climatology gave a range of 1-7 nM surface water DMS with higher concentrations in the oceans occurring in the higher latitudes with a generally increasing trend in DMS seawater concentrations during the summer. These reported higher DMS concentrations in regions labeled as Atlantic Arctic (ARCT), Atlantic Subarctic (SARC) and Pacific sub-Arctic Gyre (PSAE) in Lana et al. [2011] corresponding to the areas with higher annual mean primary productivity as given in Table 2 .

[17] The MSA weighted Seibert plots in Figure 4 give an indication of source regions corresponding to high MSA levels. During the decades of higher MSA concentrations (1980-1989, Figure 4a; 2000-2009, Figure 4c), the 7 day back trajectories reaching Alert crossed regions of typically higher primary productivity (Table 2 ) and DMS concentrations [Lana et al., 2011]: regions 2, 3, and 4 (BS, KS, GS, NNS, BFB as well as the Arctic region NE of Greenland [Perrette et al., 2011] and the open Atlantic Ocean). During the decade of lower MSA concentrations (1990-1999), the weighted Seibert analysis suggests lower MSA source strength in the regions such as GS during the spring and GS/ NNS during the summer than in the flanking decades, and that the main MSA source regions were the regions 2, 3, and 4 (BS, NNS, LS and BFB), consistent with the major changes in the direction of trajectory (Table 2). Higher MSA concentrations were measured at Ny-Ålesund from the direction of same source regions that influenced Alert (Figures $4 \mathrm{~d}$ and $4 \mathrm{e}$ ). The sparseness in the Seibert analysis for 2000-2004 (Figure 4e) at Ny-Ålesund is due to using only 4 years of data but the analysis indicates the same source regions as 2000-2009 at Alert (Figure 4c). During the spring and summer, Barrow shows a higher tendency of MSA from region 1 (BRS/CS/ESS), Pacific Ocean and region 2 (BS) (Figure 4f). 


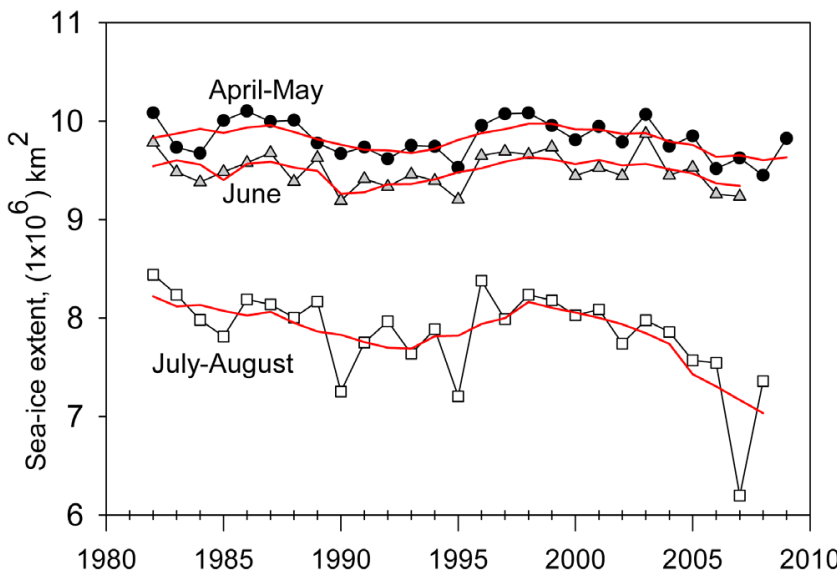

Figure 5. Averaged sea ice extent for April-May, June, and July-August from 1982 to 2009. The red line indicates five-point running averages of the sea ice extent from 1982 to 2009. Small variations in the sea ice extent are evident in April-May and June. The largest decline in sea ice extent occurred in July-August after 2000, especially in 2007.

\subsection{Relationship to Sea Ice Extent}

[18] During the 30 year period, the interannual variation in the average Arctic sea ice extent is smaller during April-May and June than the July-August period (Figure 5). A variation of $6 \%$ in the amplitude from highest to lowest sea ice extent was found for April-May and June. A decline in July-August sea ice extent is observed from the 1980 s to early 1990 s, followed by a recovery in the mid-1990s. This is followed by a more rapid decline in July-August sea ice extent than in April-May and June after 1998. The largest decline in the sea ice extent of $4 \%$ was found in April-May and $12.5 \%$ in July-August since 1998.

[19] Plots of MSA concentrations versus averaged sea ice extent for the region north of $70^{\circ} \mathrm{N}$ are shown in Figure 6, with regression (r) and significance of regression $\mathrm{p}$ for all data separated by April-May, June, and July-August and color coded by decade. To increase the number of data points, MSA and sea ice extent data from individual months were considered in the regression; i.e., monthly averages of April and May were used separately in the April-May period. The regression lines in Figure 6 corresponded to all data from 1980 to 2009. Significant regressions exist for $p<0.01$. At Alert, there is a significant negative correlation between MSA and sea ice extent for the spring data that includes all (a) Alert
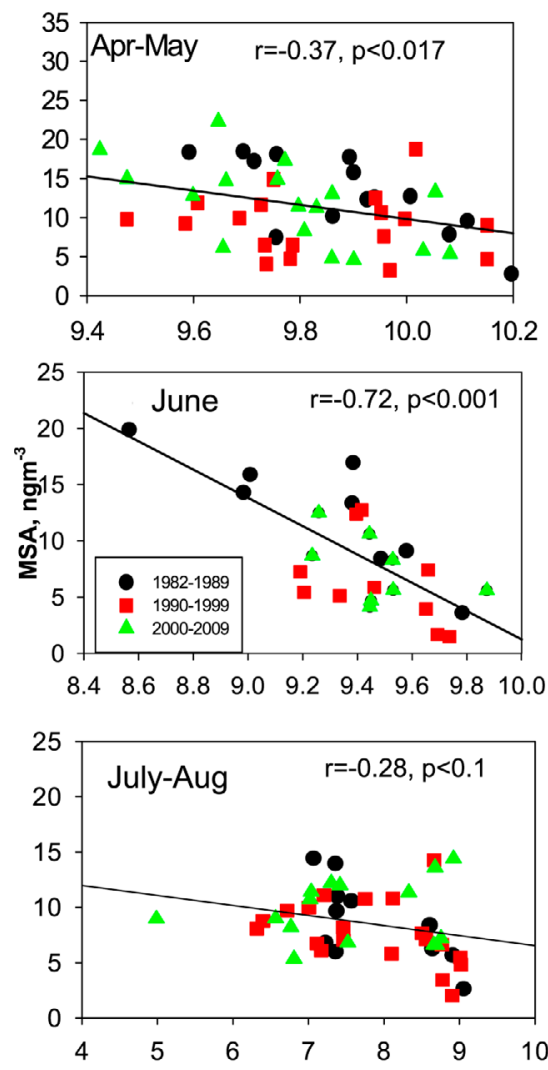

(b) Barrow
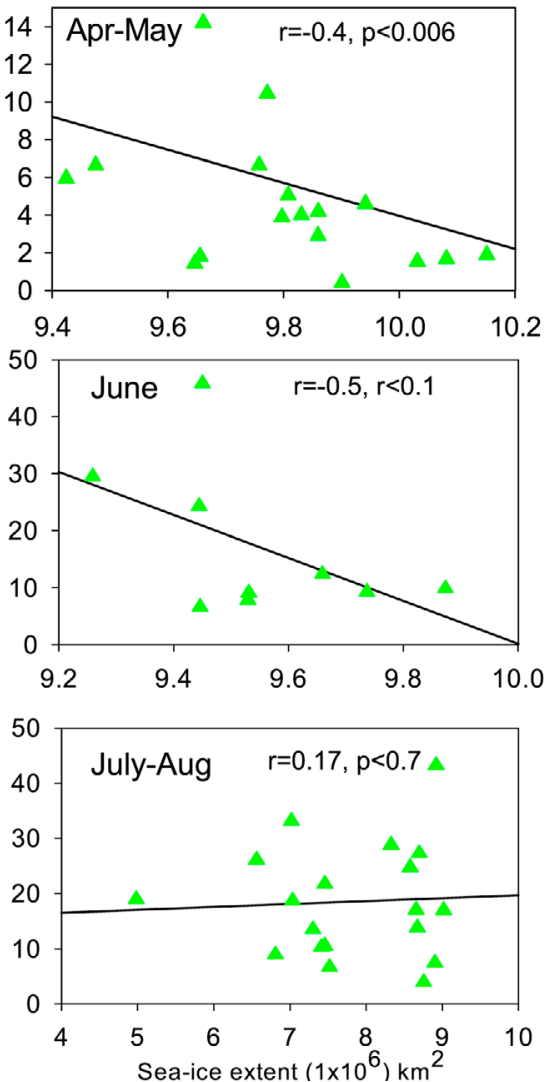

(c) Ny-Ålesund
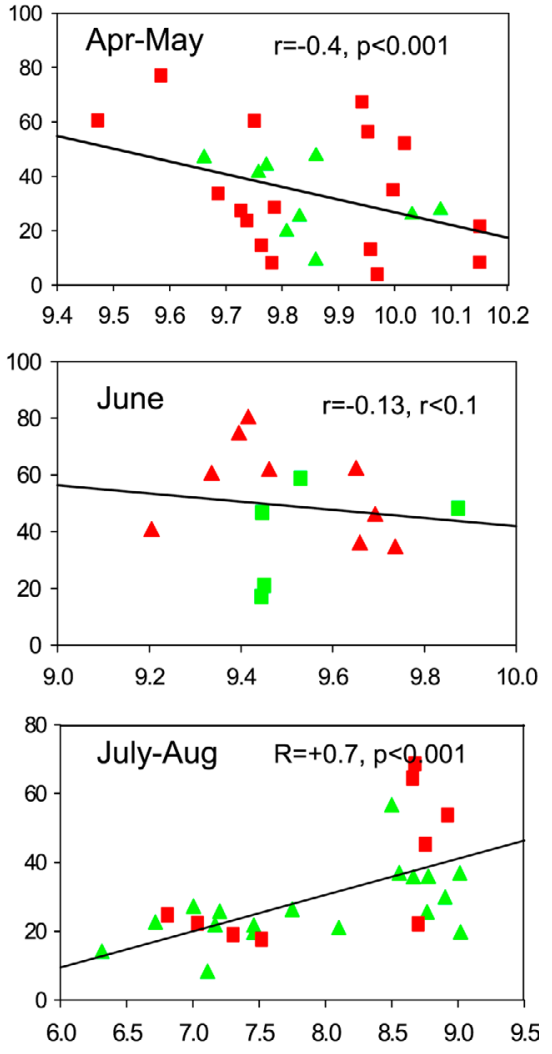

Figure 6. Regression correlations among MSA concentrations at (a) Alert, (b) Barrow, and (c) NyAllesund and sea ice extent north of $70^{\circ} \mathrm{N}$ for the three periods. Here $\mathrm{r}$ is the correlation coefficient and $\mathrm{p}$ values indicate, e.g., chance of the existence of a correlation ( $t$ test with two-tailed distributions with unequal variance). 
decades. Results at Alert also show strongest negative correlations of MSA with increasing sea ice extent $(\mathrm{r}=-0.8$, $\mathrm{p}<0.017$ ) for 2000-2009. During June, negative correlations of the MSA concentrations at Alert with increasing ice extent are significant and strongest for all data $(\mathrm{r}=-0.72$, $\mathrm{p}<0.001)$. One interesting observation in July-August at Alert is that although the overall correlation is not significant, there is a change in slope in the correlations from negative in 1980s (black circles) to positive in 2000s (green triangles). Comparing the sea ice extent among the decades also indicate that there isn't a clear trend in the sea ice extent but lower sea ice in the 1990s and 2000s as compared to 1980s.

[20] At Barrow, there is significant correlation between MSA and sea ice extent only for the spring period. At NyÅlesund, MSA concentrations exhibit a negative correlation with the sea ice extent in spring and June, and a positive correlation in July-August during both decades.

[21] We further examined if the tendencies in MSA in relation to sea ice extent were region specific. Sea ice extent was determined for the potential source regions as depicted by the Seibert plots in Figure 4 and Table 2. Results in Table 3 confirm that for April-May and June periods, MSA concentrations at all measurement sites are negatively correlated (significant to $\mathrm{p}<0.01$ ) with the sea ice extent in various source regions.

[22] MSA concentrations also were found to increase with increasing sea surface temperature (SST), air temperature (T) and decreasing wind speed (WS) for all source regions during the spring (Table 3). Overall, during the summer, there were no significant relationships. The exceptions to this were significant increase in MSA with increase in sea ice extent from region 2 at Alert during 2000-2008 and from regions 2 and 4 in the last two decades at Ny-Ålesund (also shown in Figure 6).

\section{Discussion}

[23] Since the three Arctic sites are far apart, they are influenced by different source regions and transport pathways which lead to differences in observed MSA concentrations. In this section, we will discuss the factors that influence the MSA concentrations at these locations including differences in the seasonal cycles, trends in MSA and whether recent increases in the MSA concentrations are related to recent opening up of the Arctic Ocean.

\subsection{Seasonal Variation in MSA at Three Sites}

[24] The differences in the MSA seasonal cycles between Alert, Barrow and Ny-Ålesund (Figure 2) are attributable to differences in source region influences, oxidizing potential during atmospheric transport, boundary layer dynamics and depositional losses. The seasonal cycle in MSA also corresponds to that of the solar irradiance (yellow line shaded with gray) as seen in Figure 2. Increase in solar irradiance is associated with increase in DMS producing phytoplankton, production of DMS in the ocean and exchange to the atmosphere. Li et al. [1993] found a springtime correlation between MSA at Alert and sea surface temperature anomalies in the northern North Atlantic Ocean, suggesting that springtime MSA at Alert mostly originates from the subArctic phytoplankton blooms. These sub-Arctic regions, that include MIZs, are more productive [Perrette et al., 2011] and have been linked to strong DMS producing phytoplankton in the spring [Turner and Liss, 1985; Lancelot et al., 1993; Leck and Persson, 1996; Sharma et al., 1999]. However, source regions influencing Barrow such as the North Pacific Ocean and the frozen BRS/CS (Figure 4), have lower productivity in March, which may explain the lag of one month in springtime MSA at Barrow and Alert. The highest potential DMS production in the Arctic Ocean occurs in spring and summer, due to the reduction in ice and increased solar insolation [Bouillon et al., 2002; Vallina and Simó, 2007]. A plausible reason for a factor of 3 higher MSA during the summer at Barrow than Alert is due to closer proximity to productive MIZ in region 1 (BRS/CS/ESS) in the western Arctic. In comparison to Alert and Barrow, highest MSA concentrations were measured at Ny-Ålesund as it is located closer to the MIZ in the eastern Arctic, open North Atlantic region and productive Nordic/Barents Seas. Ny-Ålesund has a milder climate than Barrow and Alert due to a dominant southerly to southwesterly atmospheric transport in combination with warm Norwegian currents bringing water into the archipelago and into the Barents Sea [Isaksson et al., 2005]. A recent satellite image of the Barents Sea shows a DMS producing phytoplankton bloom during the summer in this region (http://www.sciencedaily.com/releases/2011/08/ 110826085149.htm). Depositional losses in the Arctic are lower during the spring and increase during the summer due to higher scavenging by precipitation [Barrie, 1986]. Differences in the scavenging rates at these sites might influence the differences in MSA measured during the summer.

[25] Boundary Mixing Height (BMH) could play a role in the seasonal variation of the atmospheric MSA concentrations. Elevations of the three sites are variable with Barrow at sea level, Alert at $250 \mathrm{~m}$ and Ny-Ålesund at $474 \mathrm{~m}$ asl, where Ny-Ålesund site is above the boundary mixing height most of the time in the spring [Nyeki et al., 2005] and within the BMH during the summer. Warming of the SST and atmospheric temperature would both tend to bring more DMS/MSA up to the Ny-Ålesund and the Alert sampling sites with increasing boundary mixing heights, but less so at Barrow which is at sea level. It can be also be said that a reduction in concentration might be expected due to dilution at the Ny-Ålesund and Alert sites relative to Barrow, but this would depend on sea surface and terrestrial temperatures, and the difference between them, for each sampling period. Instead, MSA concentrations at $\mathrm{Ny}$-Ålesund are considerably elevated relative to Barrow and Alert implying it is closer to a region of high productivity (and DMS).

\subsection{Tendencies in MSA}

[26] There are variations in the trends in MSA at Alert with increasing trends since 1998 (Figure 3a). Lowest MSA concentrations at Alert for 1990-1999 correspond to a slight change in transport frequencies with a decrease in frequency from source region 3 to an increase from region 1 (Table 2) compared to other decades. Along with these changes in trajectories, plankton records show reduced planktonic abundance over the NNS region during the 1990s [Reid et al., 1998] that could have resulted in lower DMS emissions and thus MSA. The reduced planktonic abundance may have been due to cooler and fresh water input with lower salinity possibly linked to a shift in ocean circulation after 1988 and changes in the North Atlantic Oscillation (NAO) [Dickson, 


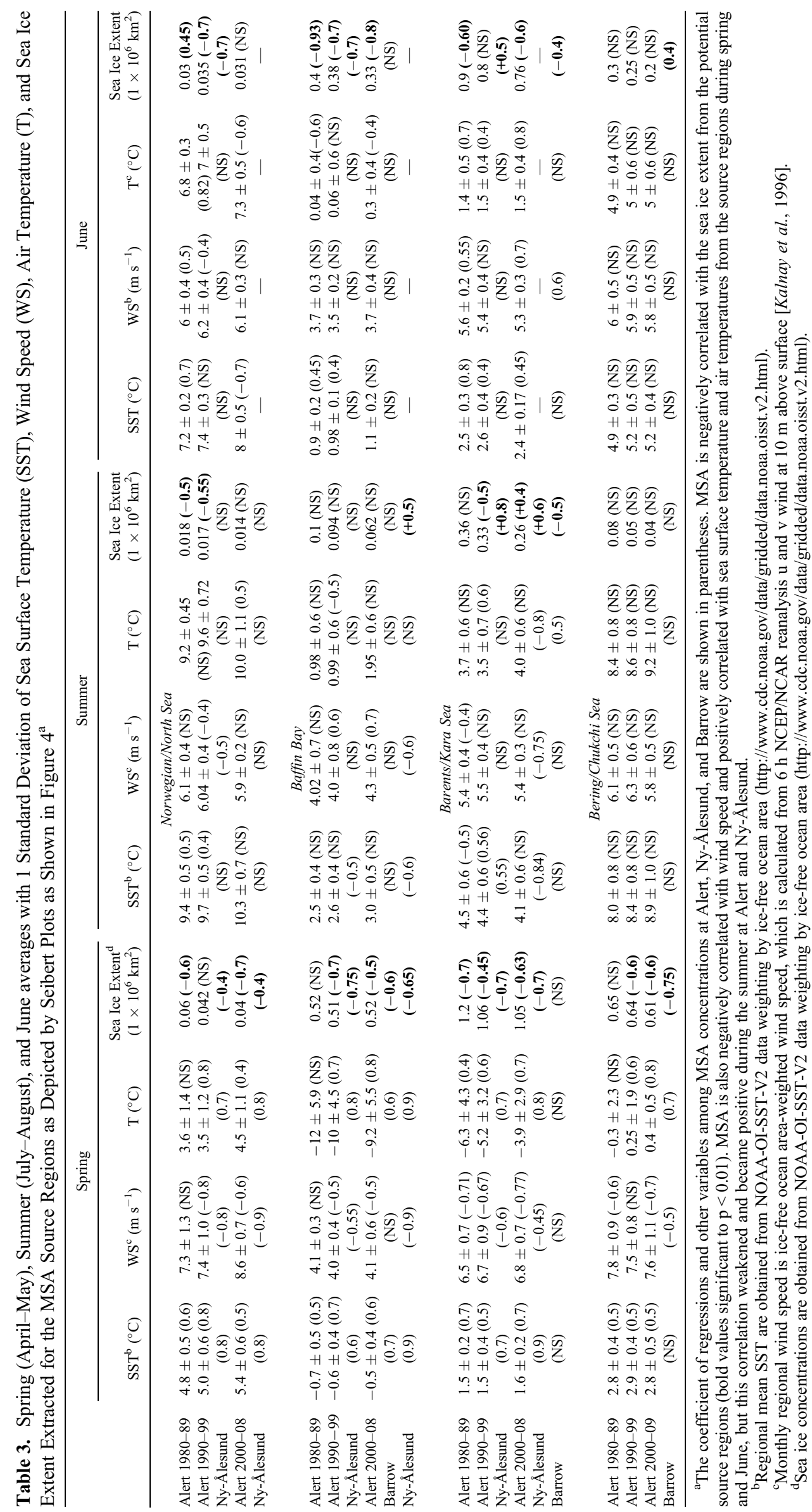


1997; Dickson et al., 2000]. The Seibert plots (Figures 4a and 4b) also support this shift in source regions in the 1990-1999. Higher MSA is associated with trajectories from region 3 (NNS and Labrador) during the spring and region 4 (BFB) during the summer. There is a significant increase in MSA since 1998 at this site in June and July-August (Figure 3a). Since 2000 , the \% frequencies in the clusters of 7 day back trajectories returned to 1980-1989 values suggesting another shift in the circulation (Table 2). Seibert analysis also supported higher MSA since 2000 from the same source regions such as regions 2 (BS/KS), 3 (NNS) and 4 (BFB) as in 19801989.

[27] Ten years of data at Barrow show a significant increasing trend of $8.3 \% \mathrm{yr}^{-1}$ only in July-August. There is significant increase in MSA concentrations from 1998 to 2006 but MSA levels decreased in 2007 to 2000 levels. The trends in MSA at Barrow are different from trends at Alert in the last decade as they are influenced by different source regions. Figure $4 \mathrm{f}$ shows higher MSA corresponding to the direction of region 1 (BRS/CS) and North Pacific Ocean as potential source in spring and regions 1 and 2 (ESS/BS/KS) and Siberian coast as a source in the summer.

[28] Although similar source regions $(2,3$ and warm Atlantic Ocean in Figures $4 \mathrm{~d}$ and $4 \mathrm{e}$ ) are found to influence Ny-Ålesund and Alert, the largest change in MSA trends since 2000 were found at Ny-Ålesund due to its closer proximity to the MIZ (Figure 4d). In comparison to NyÅlesund, the change in trends at Alert in 1998-2009 are smaller as Alert is located farther away from the MIZ resulting in enhanced total depositional losses. Air masses from the source regions cover a large fetch over the frozen Arctic Ocean before arriving at Alert.

[29] Other parameters such as $\mathrm{T}$ and SST at various source regions have a positive influence on MSA concentrations at the three sites but MSA is negatively correlated with wind speed. T and SST have increased in all source regions from 1980 to 2009. It is difficult to distinguish which one of the two is the likely cause for changes in MSA. Region 3 (NNS) is the warmest source region but the largest change in $\mathrm{T}$ occurred in region 4 (Baffin Bay) where the air temperature increased by up to $2.8^{\circ} \mathrm{C}$ in the spring and $0.9^{\circ} \mathrm{C}$ in the summer from 1980 to 1989 to $2000-2009$ (Table 3). Air temperature also increased by $2.4^{\circ} \mathrm{C}$ and $0.3^{\circ} \mathrm{C}$ during the spring and summer in the Barents and Kara regions. Change in air temperature can affect the branching ratio of MSA and sulphate from DMS oxidation by $\mathrm{OH}$ radicals; a higher yield of MSA is obtained at lower temperatures [von Glasow and Crutzen, 2004]. Trends in MSA concentrations are not directly linked with the changes in air temperature over the past three decades at Alert and in DMS source regions (Table 3 ). In any case, the warming in air temperature noted here would result in decrease in the MSA/ sulphate branching ratio by less than 13\% [Bates et al., 1992]. So the effect of T on MSA concentration is opposite. This indicates that increase in $\mathrm{T}$ does not influence the trends in MSA directly. Increase in T could influence the boundary layer dynamics bringing up air masses to $\mathrm{Ny}$-Ålesund site. MSA concentrations have increased at Alert since 2000. T in turn can affect SST which is related to increase in the production of DMS producing biota.

[30] Warmer ocean temperature has been previously associated with higher MSA [ $\mathrm{Li}$ et al., 1993] due to enhancement of DMS related phytoplankton production in the source regions [O'Dwyer et al., 2000; Isaksson et al., 2005]. In the last decade, the SST has increased in all source regions during the spring and summer relative to the 1980-1989 period. Region 3 is warmest among all source regions. The largest change in SST has occurred in the summer during the three decades $\left(0.9^{\circ} \mathrm{C}\right)$ in the regions 4 (Norwegian) and 1 (Bering/Chukchi seas) which may be the regions supporting an increase in DMS source strength and thus MSA since 2000 as indicated by the Seibert Plots.

[31] The dependence of MSA concentrations and trends on wind speed is complex as winds not only control the depth of the ocean upper mixed layer where DMS production occurs but also DMS exchange from water to the atmosphere. Based on studies of the open ocean, it would be expected that MSA increases with increasing winds as the DMS fluxes increase [Huebert et al., 2010; Nightingale et al., 2000]. However, in this study the location where wind speed and MSA are measured differs; winds are over DMS source regions. A plausible reason is that surface seawater DMS concentrations are generally higher under low wind speed conditions since there is less mixing of the surface mixed layer. Over the three decades considered here, springtime wind speeds have increased in regions $2(\mathrm{BS} / \mathrm{KS}$ ) and 3 (NNS) which are regions associated with higher MSA. This causes the argument that increasing winds have not supported the increasing trends in the MSA at all sites since 2000.

\subsection{Influence of Sea Ice on MSA}

[32] Ice cover not only limits DMS exchange between the ocean and atmosphere, but also prevents production of DMS producing biota [Clarke and Ackley, 1984]. When sea ice retreats, more light is available to algal DMS production and also facilitates sea to air exchange through the removal of the ice barrier and potentially bubble bursting under low and high wind conditions [Leck and Persson, 1996]. Strong and significant correlations among the MSA measured at the sites and sea ice extent (Figure 6 and Table 3) north of $70^{\circ} \mathrm{N}$ and from various source regions strengthen the argument that MSA concentrations have increased with decline in the sea ice extent during spring (April-May) and June. Similar results were also found in the analysis of a Svalbard ice core that suggested an increase in MSA concentrations in association with decline in sea ice cover [O'Dwyer et al., 2000]. In the current study, this relationship breaks down in July-August as the MIZ moved northward.

[33] The change in sea ice extent north of $70^{\circ}$ latitude is small during April-May, but the MIZ moves progressively in the period (Figures $4 \mathrm{a}$ and $4 \mathrm{c}$ ); the northward progressions are especially pronounced in the eastern Arctic in April-May and in the western Arctic in July-August. Our results suggest that the northern progression of the MIZ in the Arctic contributed significantly to the negative correlations between sea ice extent and MSA concentrations during April-May and June. This was recently confirmed by a study based on SeaWiFS imagery showing a synoptic-scale propagation of ice edge phytoplankton blooms following the receding sea ice [Perrette et al., 2011]. For the year 2007 when sea ice concentration in the Arctic reached its minimum, Perrette et al. [2011] showed that the melt season could span from day 60 (1 March) in the Atlantic sector to day 250 (7 September) at high latitudes with the majority of 
the melting occurring from June onward. We hypothesize that by July-August the ice edge has receded sufficiently far from areas of higher productivity such that any effect related to the ice edge is lost. By August, the solar irradiance is on the decline (Figure 2), decreasing the source strength of MSA as conversion of DMS to MSA is a photochemical process in the atmosphere. This may have resulted in the reversal in correlation from negative to positive in 2000-2009 at Alert and in the last two decades at Ny-Ålesund (Table 3). At Barrow, the lack of significant negative correlation of MSA to sea ice extent in June and summer may reflect the transport from more distant ice-free MSA source regions (e.g., North Pacific Ocean) or by other environmental factors. To more accurately take the complex influence of transport and ice-controlled sources into account, a more detailed analysis with an atmosphere-ocean-coupled model with dynamic ice and a marine biogenic DMS source is needed.

\section{Conclusions}

[34] Our results suggest that the recorded variations in MSA concentrations at Alert are linked to changes in DMS emissions in the source regions and changes in the frequency of air mass transport from source regions. As indicated by the regression analysis, MSA concentrations have increased with decreasing sea ice extent since 1998 during the April-May period at all three sites and in June at Alert. However, there is no such relationship for July-August when the ice extent was lower. At Alert, the slope changed in the summer from negative during the 1980-1989 period to positive during 2000-2008. A positive slope is also found in the strong MSA correlations with the sea ice extent at Ny-Ålesund during the summer. This suggests that the increase in MSA in spring and June is related to the northward progression of the DMS-rich MIZ toward the measurement sites. By the summer, the MIZ has moved north of the source regions that impact the measurement sites and southward atmospheric transport is minimal. Although seawater surface DMS concentrations may still be high in August [Leck and Persson, 1996] in the local source regions, the atmospheric conversion to MSA has slowed due to decreasing solar irradiance (Figure 2). This may have resulted in a positive correlation in MSA with decreasing sea ice extent during summer at Alert and Ny-Ålesund (Figure 6). At Alert, the slope progressively changed from negative during 1980-1989 to positive during 2000-2008. No such relationship was evident at Barrow in June and summer. A continued decline in the seasonal Arctic ice cover and earlier northerly movement of the DMS productive MIZ may result in increased DMS source strengths for the Arctic atmosphere when the solar irradiance is at its peak. This could lead to ice edge blooms propagating over much greater distances as the melt season becomes longer. To predict the impact of such an increase on cloud properties and radiative effects, more knowledge of the relationships between biota at the marginal sea ice edge, DMS in air and its oxidation to MSA and sulfate is needed.

[35] Acknowledgments. The authors would like to thank Joe Kovalick, Armand Gaudenzi, and Dave Halpin for the technical support; Tom Agnew for very important discussions and data for sea ice concentrations for the Seibert plots; the operators at Alert and Ny-Ålesund over the years for maintaining the program; the late Jan Erik Hanssen from the Norwegian Institute for Air Research for his assistance in obtaining the samples from Ny-Ålesund during more than a decade; and the members of CFS Alert for site maintenance and flights to Alert. One of us (W.M.) also acknowledges the Belgian Federal Science Policy Office and the Fonds voor Wetenschappelijk Onderzoek-Vlaanderen for financial support and Geert Ducastel, Koen Beyaert, Xuguang Chi, and Wan Wang for assistance in the chemical analysis of the samples from Ny-Ålesund.

\section{References}

Arrigo, K. R., G. van Dijken, and S. Pabi (2008), Impact of a shrinking Arctic ice cover on marine primary production, Geophys. Res. Lett., 35, L19603, doi:10.1029/2008GL035028.

Barrie, L. A. (1986), Arctic air pollution: An overview of current knowledge, Atmos. Environ., 20, 643-663, doi:10.1016/0004-6981(86) 90180-0.

Bates, T. S., J. A. Calhoun, and P. K. Quinn (1992), Variations in the methanesulfonate to sulfate molar ratio in submicrometer marine aerosol particles over the South Pacific Ocean, J. Geophys. Res., 97, 9859-9865, doi:10.1029/92JD00411.

Bigg, E. K., and C. Leck (2008), The composition of fragments of bubbles bursting at the ocean surface, J. Geophys. Res., 113, D11209, doi:10.1029/2007JD009078.

Bouillon, R.-C., P. A. Lee, S. J. de Mora, M. Levasseur, and C. Lovejoy (2002), Vernal distribution of dimethylsulphide, dimethylsulphoniopropionate, and dimethylsulphoxide in the North Water in 1998, Deep Sea Res., Part II, 49, 5171-5189.

Ceburnis, D., C. D. O’Dowd, G. S. Jennings, M. C. Facchini, L. Emblico, S. Decesari, S. Fuzzi, and J. Sakalys (2008), Marine aerosol chemistry gradients: Elucidating primary and secondary processes and fluxes, Geophys. Res. Lett., 35, L07804, doi:10.1029/2008GL033462.

Charlson, R. J., J. E. Lovelock, M. O. Andreae, and S. G. Warren (1987), Oceanic phytoplankton, atmospheric sulphur, cloud albedo and climate, Nature, 326, 655-661, doi:10.1038/326655a0.

Clarke, D. B., and S. F. Ackley (1984), Sea ice structure and biological activity in the Antarctic marginal ice zone, J. Geophys. Res., 89, 2087-2095, doi:10.1029/JC089iC02p02087.

Dickson, B. (1997), From the Labrador Sea to global change, Nature, 386, 649-650, doi:10.1038/386649a0.

Dickson, R. R., T. J. Osborn, J. W. Hurrell, J. Meincke, J. Blindheim, B. Adlandsvik, T. Vinje, G. Alekseev, and W. Maslowski (2000), The Arctic Ocean response to the North Atlantic Oscillation, J. Clim., 13, 2671-2696.

Dorling, S. R., T. D. Davies, and C. E. Pierce (1992), Cluster analysis: A technique for estimating the synoptic meteorological controls on air and precipitation chemistry-Method and applications, Atmos. Environ., Part A, 26, 2575-2581.

Facchini, M. C., et al. (2008), Primary submicron marine aerosol dominated by insoluble organic colloids and aggregates, Geophys. Res. Lett., 35, L17814, doi:10.1029/2008GL034210.

Gabric, A. J., B. Qu, P. Matrai, and A. C. Hirst (2005), The simulated response of dimethylsulfide production in the Arctic Ocean to global warming, Tellus, Ser. B, 57, 391-403, doi:10.1111/j.1600-0889.2005. 00163.x.

Gosselin, M., M. Levasseur, P. A. Wheeler, R. A. Horner, and B. C. Booth (1997), New measurements of phytoplankton and ice algal production in the Arctic Ocean, Deep Sea Res. Part II, 44, 1623-1644, doi:10.1016/ S0967-0645(97)00054-4.

Hawkins, L. N., and L. M. Russell (2010), Polysaccharides, proteins, and phytoplankton fragments: Four chemically distinct types of marine primary organic aerosol classified by single particle spectromicroscopy, Adv. Meteorol., 2010, 612132, doi:10.1155/2010/612132.

Huebert, B. J., B. W. Blomquist, M. X. Yang, S. D. Archer, P. D. Nightingale, M. J. Yelland, J. Stephens, R. W. Pascal, and B. I. Moat (2010), Linearity of DMS transfer coefficient with both friction velocity and wind speed in the moderate wind speed range, Geophys. Res. Lett., 37, L01605, doi:10.1029/2009GL041203.

Hunt, G. L., Jr., P. Stabeno, G. Walters, E. Sinclair, R. D. Brodeur, J. M. Napp, and N. A. Bond (2002), Climate change and control of the southeastern Bering Sea pelagic ecosystem, Deep Sea Res., Part II, 49, $5821-5853$.

Isaksson, E., T. Kekonen, J. Moore, and R. Mulvaney (2005), The methanesulfonic acid (MSA) record in a Svalbard ice core, Ann. Glaciol., 42, 345-351.

Kalnay, E., et al. (1996), The NCEP/NCAR 40-year reanalysis project, Bull. Am. Meteorol. Soc., 77, 437-471.

Kettle, A. J., et al. (1999), A global database of sea surface dimethylsulfide (DMS) measurements and a procedure to predict sea surface DMS as a function of latitude, longitude, and month, Global Biogeochem. Cycles, 13, 399-444, doi:10.1029/1999GB900004.

Kulmala, M., et al. (2007), Toward direct measurement of atmospheric nucleation, Science, 318, 89-92, doi:10.1126/science.1144124. 
Lana, A., et al. (2011), An updated climatology of surface dimethlysulfide concentrations and emission fluxes in the global ocean, Global Biogeochem. Cycles, 25, GB1004, doi:10.1029/2010GB003850.

Lancelot, C., S. Mathot, C. Veth, and H. de Baar (1993), Factors controlling phytoplankton ice-edge blooms in the marginal ice-zone of the northwestern Weddell Sea during sea ice retreat 1988: Field observations and mathematical modelling, Polar Biol., 13, 377-387, doi:10.1007/ BF01681979.

Leck, C., and E. K. Bigg (2005a), Biogenic particles in the surface microlayer and overlaying atmosphere in the central Arctic Ocean during summer, Tellus, Ser. B, 57, 305-316.

Leck, C., and E. K. Bigg (2005b), Source and evolution of the marine aerosol-A new perspective, Geophys. Res. Lett., 32, L19803, doi:10.1029/ 2005GL023651.

Leck, C., and C. Persson (1996), The central Arctic Ocean as a source of dimethyl sulfide: Seasonal variability in relation to biological activity, Tellus, Ser. B, 48(2), 156-177, doi:10.1034/j.1600-0889.1996.t01-100003.x.

Leck, C., M. Norman, E. K. Bigg, and R. Hillamo (2002), Chemical composition and sources of the high Arctic aerosol relevant for cloud formation, J. Geophys. Res., 107(D12), 4135, doi:10.1029/2001JD001463.

Levasseur, M., M. Gosselin, and S. Michaud (1994), A new source of dimethylsulfide (DMS) for the arctic atmosphere: Ice diatoms, Mar. Biol., 121(2), 381-387, doi:10.1007/BF00346748.

Li, S.-M., and L. A. Barrie (1993), Biogenic sulfur aerosol in the Arctic troposphere: 1. Contributions to total sulfate, J. Geophys. Res., 98, 20,613-20,622, doi:10.1029/93JD02234.

Li, S.-M., L. A. Barrie, and A. Sirois (1993), Biogenic sulfur aerosol in the Arctic troposphere: 2. Trends and seasonal variations, J. Geophys. Res., 98, 20,623-20,631, doi:10.1029/93JD02233.

Loeng, H., et al. (2005), Marine systems, in Artic Climate Impact Assessment, p. 493, Cambridge Univ. Press, Cambridge, U. K.

Maenhaut, W. (1997), Composition and origin of the regional atmospheric aerosol at great distance from anthropogenic source areas. Assessment of the extent of the anthropogenic perturbation. Belgian Impulse Programme Global Change 1990-1996, final report, 105 pp., Fed. Off. for Sci., Tech. and Cult. Affairs, Brussels, Belgium.

Maenhaut, W., G. Ducastel, K. Beyaert, and J. E. Hanssen (1994), Chemical composition of the summer aerosol at Ny Ålesund, Spitsbergen, and relative contribution of natural and anthropogenic sources to the non-sea-sal sulfate, in Proceedings of EUROTRAC Symposium '94, edited by P. M. Borrell et al., pp. 467-471, SPB Acad., The Hague, Netherlands.

Maenhaut, W., K. Beyaert, G. Ducastel, V. Havránek, R. Salomonovic, and J. E. Hanssen (1997), Long-term measurements of the atmospheric aerosol composition at Ny Ålesund, Spitsbergen, in Proceedings of EUROTRAC Symposium '96, vol. 1, edited by P. M. Borrell et al., pp. 273-276, Comput. Mech., Southampton, U. K

Maenhaut, W., J. Schwarz, J. Cafmeyer, and X. Chi (2002), Aerosol chemical mass closure during the EUROTRAC-2 AEROSOL Intercomparison 2000, Nucl. Instrum. Methods Phys. Res., Sect. B, 189, 233-237, doi:10.1016/S0168-583X(01)01048-5.

Matrai, P. A., and M. Vernet (1997), Dynamics of the vernal bloom in the marginal ice zone of the Barents Sea: Dimethyl sulfide and dimethylsulfoniopropionate budgets, J. Geophy. Res., 102(C10), 22,965-22,979.

Nightingale, P. D., G. Malin, C. S. Law, A. J. Watson, P. S. Liss, M. I. Liddicoat, J. Boutin, and R. C. Upstill-Goddard (2000), In situ evaluation of air-sea gas exchange parameterizations using novel conservative and volatile tracers, Global Biogeochem. Cycles, 14, 373-387, doi:10.1029/ 1999GB900091.

Norman, A. L., A. Sanusi, D. Toom-Sauntry, S. L. Gong, and L. A. Barrie (2005), Arctic biogenic aerosol sulphate using isotope apportionment techniques: 1993-2003, Eos Trans. $A G U$, 86(52), Fall Meet. Suppl., Abstract A31B-0840.

Nyeki, S., G. Coulson, I. Colbeck, K. Eleftheriadis, U. Baltensperger, and H. J. Beine (2005), Overview of aerosol microphysics at Arctic sunrise: Measurements during the NICE renoxification study, Tellus, Ser. B, 57, 40-50.
O’Dowd, C. D., M. C. Facchini, F. Cavalli, D. Ceburnis, M. Mircea, S. Decesari, S. Fuzzi, Y. J. Yoon, and J.-P. Putaud (2004), Biogenically driven organic contribution to marine aerosol, Nature, 431, 676-680, doi:10.1038/nature02959.

O’Dwyer, J., E. Isaksson, T. Vinje, T. Jauhiainen, J. Moore, V. Pohjola, R. Vaikmäe, and R. S. W. van de Wal (2000), Methanesulfonic acid in a Svalbard ice core as an indicator of ocean climate, Geophys. Res. Lett., 27(8), 1159-1162, doi:10.1029/1999GL011106.

Perrette, M., A. Yool, G. D. Quartly, and E. E. Popova (2011), Near-ubiquity of ice-edge blooms in the Arctic, Biogeosciences, 8, 515-524, doi:10.5194/bg-8-515-2011.

Petters, M. D., and S. M. Kreidenweis (2007), A single parameter representation of hygroscopic growth and cloud condensation nucleus activity, Atmos. Chem. Phys., 7, 1961-1971, doi:10.5194/acp-7-1961-2007.

Quinn, P. K., and T. S. Bates (2011), The case against climate regulation via oceanic phytoplankton sulphur emissions, Nature, 480, 51-56, doi:10.1038/nature10580.

Quinn, P. K., T. L. Miller, T. S. Bates, J. A. Ogren, E. Andrews, and G. E. Shaw (2002), A 3-year record of simultaneously measured aerosol chemical and optical properties at Barrow, Alaska. J. Geophys. Res. 107(D11), 4130, doi:10.1029/2001JD001248.

Quinn, P. K., G. Shaw, E. Andrews, E. G. Dutton, T. Ruoho-Airola, and S. L. Gong (2007), Arctic haze: Current trends and knowledge gaps, Tellus, Ser. B, 59, 99-114.

Quinn, P. K., T. S. Bates, K. Schulz, and G. E. Shaw (2009), Decadal trends in aerosol chemical composition at Barrow, Alaska: 1976-2008, Atmos. Chem. Phys., 9, 8883-8888, doi:10.5194/acp-9-8883-2009.

Reid, P. C., M. Edwards, H. G. Hunt, and A. J. Warner (1998), Phytoplankton change in the North Atlantic, Nature, 391, 546, doi:10.1038/35290.

Russell, L. M., L. N. Hawkins, A. A. Frossard, P. K. Quinn, and T. S. Bates (2010), Carbohydrate-like composition of submicron atmospheric particles and their production from ocean bubble bursting, Proc. Natl. Acad. Sci. U. S. A., 107, 6652-6657, doi:10.1073/pnas.0908905107.

Seibert, P., H. Kromp-Kolb, U. Baltensperger, D. T. Jost, M. Schwikowski, A. Kasper, and H. Puxbaum (1994), Trajectory analysis of aerosol measurements at high alpine sites, in Proceedings of EUROTRAC Symposium'94, edited by P. M. Borell et al., pp. 689-693, SPB Acad., The Hague, Netherlands.

Seibert, P., F. Beyrich, S.-E. Gryning, S. Joffre, A. Rasmussen, and P. Tercier (2000), Review and intercomparison of operational methods for the determination of the mixing height, Atmos. Environ., 34, 1001-1027.

Seidel, D. J., C. O. Ao, and K. Li (2010), Estimating climatological planetary boundary layer heights from radiosonde observations: Comparison of methods and uncertainty analysis, J. Geophys. Res., 115, D16113, doi:10.1029/2009JD013680.

Serreze, M. C., M. M. Holland, and J. Stroeve (2007), Perspectives on the Arctic's shrinking sea-ice cover, Science, 315(5818), 1533-1536, doi:10.1126/science. 1139426

Sharma, S., L. A. Barrie, D. Plummer, J. C. McConnell, P. C. Brickell, M. Levasseur, M. Gosselin, and T. S. Bates (1999), Flux estimation of oceanic dimethyl sulfide around North America, J. Geophys. Res., 104(D17), 21,327-21,342.

Sharma, S., D. Lavoué, H. Cachier, L. A. Barrie, and S. L. Gong (2004), Long-term trends of the black carbon concentrations in the Canadian Arctic, J. Geophys. Res., 109, D15203, doi:10.1029/2003JD004331.

Simó, R. (2001), Production of atmospheric sulfur by oceanic plankton: Biogeochemical, ecological and evolutionary links, Trends Ecol. Evol., 16(6), 287-294, doi:10.1016/S0169-5347(01)02152-8.

Turner, S. M., and P. S. Liss (1985), Measurements of various sulphur gases in a coastal marine environment, J. Atmos. Chem., 2, 223-232, doi:10.1007/BF00051074.

Vallina, S. M., and R. Simó (2007), Strong relationship between DMS and the solar radiation dose over the global surface ocean, Science, 315, 506-508, doi:10.1126/science.1133680.

von Glasow, R., and P. J. Crutzen (2004), Model study of multiphase DMS oxidation with a focus on halogens, Atmos. Chem. Phys., 4, 589-608, doi:10.5194/acp-4-589-2004. 